\title{
Private Prerogative, Public Purpose: Political Entrepreneurship and Management in Frederick the Great's Anti-Machiavel
}

\author{
Alexander W. Salter \\ Texas Tech University
}

\begin{abstract}
I contribute to the literature on political entrepreneurship by analyzing the role of the political entrepreneur in Frederick the Great's Anti-Machiavel. Frederick the Great (Frederick II of Prussia) is best known for turning Prussia into an international power during the mid to late eighteenth century. His perspective on governance contains many valuable insights into the nature of political entrepreneurship, the institutions within which it occurs, and its effects on material prosperity. I detail key points from AntiMachiavel that can advance scholarship on political entrepreneurship. I conclude by discussing how Frederick's insights into political entrepreneurship can be put to work.
\end{abstract}

\section{JEL Codes: B11, H11, M1, P16}

Keywords: cameralism, enlightened absolutism, entrepreneurship, Frederick the Great, political entrepreneurship, public administration

What is prudence in the conduct of every private family, can scarce be folly in that of a great kingdom.

- Adam Smith

\section{Introduction}

Political entrepreneurship has recently become a significant topic in economics, political science, and managerial science (e.g., Agarwal et al. 2009; Bernier and Hafsi 2007; Bjerregaard and Lauring 2012; Bysted and Jespersen 2014; Kivleniece and Quelin 2012; Klein et al. 2010, 2013; Leyden and Link 2015; Martin and Thomas 2013; McCaffrey and Salerno 2014; McGinnis and Ostrom 2012; Ostrom 2005; Skarbek 2016). Studies of political entrepreneurship take insights from market entrepreneurship and apply them to politics to understand the dynamics of institutional change. Theoretical studies advance our understanding of political entrepreneurship in ways that increase its applicability; empirical studies advance our understanding 
of specific historical episodes where political entrepreneurs were significant drivers of social outcomes. In this paper, I advance the theory of political entrepreneurship by exploring a historical source hitherto neglected by the literature. Specifically, I analyze the role of the political entrepreneur in Frederick the Great's Anti-Machiavel. My novel contribution concerns the institutional underpinnings of political entrepreneurship. Given the correct context, it can be more than a mere "mantra" (Beckett 2000) that political entrepreneurship should mimic commercial entrepreneurship; it can be fact.

Frederick II of Prussia (1712-1786, reigned 1740-1786), popularly known as Frederick the Great, is chiefly remembered as the monarch who established Prussia as an international power. An exemplar of the political philosophy that scholars have since dubbed "enlightened absolutism," Frederick modernized the Prussian army, spearheaded bureaucratic and judicial reforms that both increased managerial efficiency and enabled non-nobles to play a greater role in governance, and was a generous patron of the arts. His innovations in military tactics and strategy enabled him to achieve victories against great odds during the Silesian Wars and the Seven Years' War, and his writings on military science are still read in many armed forces academies. In Frederick's time, studying the writings of Niccolo Machiavelli, and especially The Prince, was a necessary component of a ruler's education. In 1739, Frederick finished writing a treatise that challenged Machiavelli's theories of statecraft. Written in French and published anonymously in 1740, Anti-Machiavel was widely read in its time, due in no small part to Voltaire, one of Frederick's favorite intellectuals, who distributed the manuscript in Amsterdam.

Whatever one's views of his reign, Frederick must be regarded as one of modernity's most skillful political entrepreneurs. His philosophy of governance, expressed most cogently in Anti-Machiavel, contains many insights that are relevant to the theory and practice of political entrepreneurship. My goal is not to conduct an exhaustive exegesis of Anti-Machiavel. Instead, I consider Frederick's philosophy in light of political entrepreneurship theory. Frederick's insights are not only of historical interest; they are inputs that can be used to advance modern political entrepreneurship studies. These insights also suggest how political entrepreneurship can contribute to good governance. To show this, the paper situates Frederick's thought in the context of eighteenth-century Germanic policy science and shows 
how interpreting Frederick in light of this intellectual context yields actionable ideas for future research.

In addition to political entrepreneurship and management, I contribute to two distinct literatures. The first is the literature on private governance and political property rights (Anderson and Hill 2004; Barzel 1997; Boettke 2011; Caplan and Stringham 2008; Ellickson 1991; Friedman 2014; Leeson 2011, 2014; Powell and Stringham 2009; Salter 2015a, b; Stringham 2015; Stringham and Zywicki 2011). Frederick ruled during a period of significant innovation in governance, and in particular the expansion of the state beyond its feudal confines. During this time, the state acquired an institutional identity distinct from the private holdings of its rulers. But despite extending governance roles to non-nobles, the state in Germanic polities such as Prussia was still characterized by hierarchical rule under the ultimate authority of a prince. Statecraft was equated with the prudent stewardship of political property rights. Studying Frederick's approach to political entrepreneurship thus yields the intriguing combination of public entrepreneurial insights derived from private management practice. These insights can help us understand not only political entrepreneurship in the abstract, but the institutional foundations that specify for political entrepreneurs what the payoffs are for various courses of action, and what feedback loops exist to discipline political-entrepreneurial behavior.

The second literature is the political economy of state formation and growth, with special emphasis on state capacity (Besley and Persson 2009, 2010, 2011; Acemoglu, Ticchi, and Vindigni2011; Acemoglu, Garcia-Jimeno, and Robinson 2015; Acemoglu, Moscona, and Robinson2016; Gennaioli and Voth 2015; Johnson and Koyama 2017). This literature argues that modern, centralized states created the conditions necessary for the extraordinary rise in Western living standards experienced in the late eighteenth century. According to this literature, these conditions included a uniform and nondiscriminatory rule of law, as well as an efficient bureaucracy that oversaw the provision of public goods and reformed taxation in a way that reduced its economic burden.

While this literature is valuable in understanding Western economic prosperity, it has not yet developed beyond "institutional morphology." These studies describe the outward changes in governance institutions, but not why those who governed behaved in a socially beneficial manner. The connection between private payoffs and social payoffs is missing. This oversight stems, in part, from the 
neglect of political entrepreneurship. Introducing the political entrepreneur as an agent of social change can provide the missing link between outcomes (e.g., sustained increases in income per capita) and institutional forms (e.g., efficient bureaucracies). If we can understand what information and incentives political entrepreneurs confronted that reconciled private interest with social interest, then we can understand why political entrepreneurs found it prudent to behave in a manner conducive to broad-based economic growth. This paper is a first attempt to understand that missing link.

I proceed as follows. Section 2 reviews the relevant political entrepreneurship literature. Section 3 provides hermeneutical context for Frederick's writings by detailing the intellectual environment surrounding those writings. This section covers the Germanic policy science known as cameralism, and the political philosophy of enlightened absolutism. Section 4 analyzes Anti-Machiavel and reconstructs Frederick's insights as inputs into the study of political entrepreneurship. Section 5 discusses the lessons for political entrepreneurship studies that follow from the previous two sections. Section 6 concludes by considering implications for political entrepreneurship within today's states, and how we should think about states themselves.

\section{The Literature on Political Entrepreneurship}

There are three main paradigms within which theories of entrepreneurship fall. The first focuses on opportunities. In this paradigm, which derives chiefly from the writings of Israel Kirzner (1973, 1997), entrepreneurship is alertness to hitherto uncaptured gains from exchange, and acting to capture those gains. In management and entrepreneurship studies, the unit of analysis is the entrepreneurial opportunity and the facets of human action relevant to alertness, such as the qualities of individual entrepreneurs (e.g., Shane and Venkataraman 2000; Shane 2003).

The second paradigm focuses on innovation. In this paradigm, which derives chiefly from the writings of Joseph Schumpeter (1911, 1939), entrepreneurship is the injection of novelty into methods of producing and distributing goods and services. Entrepreneurship results in creative destruction: the entrepreneur creates new methods of production, or even new markets, fundamentally changing the economy's "patterns of sustainable specialization and trade" (Kling 2016). In management and entrepreneurship studies, the unit of analysis is instances of economic innovation, with special focus on 
how particular entrepreneurs disrupt existing modes of production and distribution, what predicts such disruptions, and what effects such disruptions have on economic performance (e.g., Block, Fisch, and Praag 2017; van Stel, Carree, and Thurik 2005). The focus is on judgment.

In the third paradigm, which derives chiefly from the writings of Frank Knight (1921) and Ludwig von Mises (1949), entrepreneurship is purposeful human behavior under conditions of genuine (nonprobabilistic) uncertainty. The entrepreneur is an active creator of opportunities, rather than a discoverer only. When manifested in action, entrepreneurship necessarily involves resource ownership, control, and allocation. In management and entrepreneurship studies, the unit of analysis consists of human action in the context of a plan, a future-oriented structure of actions by which the entrepreneur deploys means to achieve ends (e.g., Foss and Klein 2012).

Political entrepreneurship refers to entrepreneurship in the specific nonmarket environment of the state. Of course, political entrepreneurs are not completely divorced from exchange institutions. But there is a meaningful difference between political entrepreneurs and market entrepreneurs: the former has direct recourse to a legitimized monopoly on coercion (Weber [1918] 1946), the latter indirect, if any. Within political entrepreneurship theory, the opportunities and innovation paradigms are primarily formal and structural: they are ways of describing what, at the helm of the state, political entrepreneurs do. The judgment paradigm, while it also has formal and structural elements, is primarily substantive and functional: it is a category of action, oriented toward specific ends (Foss and Klein 2012, p. 29). States, or rather those empowered to act on behalf of the state, can perceive and take advantage of opportunities, and can introduce innovations into political-economic processes and institutions. This is a consequence of entrepreneurial behavior in the context of politics. Actors can also devise plans involving market and nonmarket resources and act on them, which necessarily involves bearing uncertainty. This constitutes entrepreneurial behavior in the context of politics.

The judgment-based view of entrepreneurship, especially that which links entrepreneurship to the institution of the firm (Foss and Klein 2012), is particularly well-suited to understanding political entrepreneurship. The locus of political entrepreneurship is the state, which can be viewed as a corporate body whose institutional identity is separable from the identities of its personnel, differentiated from 
other such bodies by its legitimized monopoly on coercion. In this conception, the state and the firm have much in common.

One view of firms is that they are hierarchically structured sites of production, which own and control resources in the service of advancing a plan (Coase 1937; Hart 1995; Williamson 1996). The entrepreneur fits well with this view. "The firm, in this sense, is the entrepreneur and the assets he owns, and therefore ultimately controls," write Foss and Klein (2012, p. 40). "The theory of the firm is essentially a theory of how the entrepreneur exercises his judgmental decision-making." So far, these descriptions could fit the state and the political entrepreneur as well. However, aside from the obvious issue of coercion, there are important differences.

While firms can be modeled with a concrete objective function, states frequently cannot. In the language of Hayek (1973), states are orders, not organizations. The latter, due to internal and external factors, have a specific goal. Internally, organizations have tolerable solutions to principal-agent problems; externally, organizations exist in a competitive environment which filters out those who lack specific adaptive properties that promote survivability (Alchian 1950; Becker [1971] 2017). Thus, while particular subsets of states, such as bureaus and agencies, may be organizations-albeit ones with different objective functions than firms, since bureaus and agencies are not residual claimants to their activities_-states as a whole are orders: networks of organizations that sometimes cooperate and sometimes compete (Wagner 2016).

The perspective on political entrepreneurship I adopt draws from the above three paradigms. Substantively, I employ the judgmentbased view; descriptively, I employ the opportunities and innovations view. This places my work within the subset of political entrepreneurship studies whose primary method is to apply theoretical categories of entrepreneurship to nonmarket settings (e.g., Klein et al. 2010, 2013; Martin and Thomas 2013; McCaffrey and Salerno 2014; Skarbek 2016). An alternative strand of research, although it frequently cites and engages key arguments from the three paradigms, is driven at the margin more by empirics than theory (e.g., Bernier and Hafsi 2007; Leyden and Link 2015; Bysted and Jespersen 2014; with Ostrom 2005 as an intermediate case). This approach to political entrepreneurship is rich with institutional detail, placing chief importance on careful explication of specific cases of political entrepreneurship, and tends to be more cautious about the generalizability of employed explanations. 
I do not argue for one approach over the other. Instead, what is interesting and novel in my analysis is that I use the paradigms approach to identify a new way of thinking about political entrepreneurship, one in which political entrepreneurs' political and economic goals are necessarily entangled. It is accepted that politics is a peculiar kind of business (Wagner 2016), and this difference in institutional settings generates differential channels for the expression of entrepreneurial drives. I explore an understudied historical episode in which political entrepreneurship can be explained in the same way as commercial entrepreneurship: good political entrepreneurship, like good market entrepreneurship, can be rendered intelligible in financial terms, with value added to the polity's scarce resources as the ultimate measure of the success of both.

\section{Intellectual Antecedents: Cameralism and Enlightened Absolutism}

Cameralism (from camera or kammer, the chamber from which princes governed) refers to a broad class of writings on public finance, political economy, and applied managerial studies that began during the middle of the sixteenth century and flourished until the early nineteenth century. The cameralists were experts in Koppl's (2018) sense: rulers consulted them and paid for their advice in practical problems of royal administration, and Germanic rulers frequently employed them to manage princely estates and enterprises. Almost all the influential cameralist writers were university educated, and cameral science was a specialized discipline propounded from endowed university chairs. The cameralists' advice was very different from that of a modern economic policy analyst.

During the period of cameralism's greatest influence among scholars and rulers, economics as a distinct science had not yet developed. The principles of cameralism were not formal statements regarding the operation of a political-economic system. Instead, they were practical and actionable policies that princes could take to steward the value of their wealth and perpetuate their rule. Cameralist writers were careful to appreciate the institutional context: they were advising de jure absolute rulers, who nonetheless confronted a host of de facto economic and political constraints in exercising rule.

What follows is an overview of the cameralist principles, which contextualizes Frederick's insights into governance and can be used in modern political entrepreneurship theory. Small (1909) still provides the most thorough English-language history of thought; 
Backhaus and Wagner (1987, 2005), Salter (2016), and Wagner (2012) analyze cameralism from the perspective of modern public choice economics. From these sources we can arrive at an appreciation of cameralism as a fertile source of material for political entrepreneurship and management studies.

\section{A. The State as a Firm}

Cameralist writings reflected the political circumstances confronting German rulers and theoreticians of rule. In 1648, the Peace of Westphalia concluded the Thirty Years' War. The Peace recognized more than 300 independent Germanic polities. Internally, these polities were absolutist. The prince was sovereign within his domain. Externally, significant political and economic competition restricted the range of feasible activities a prince could undertake. Germanic princes could not afford, like the sovereigns of large states such as England and France, to be mercantilist. They lacked the power to impose tariffs and auction off monopoly property rights as a means of raising revenue. Backhaus and Wagner (1987, pp. 5-6) explain, "The cameralist thinkers accepted these circumstances and they put forth an alternative approach ... Under the cameralist approach, the ruler of a particular territory became an entrepreneur in organizing the supply of services of common interest under essentially competitive conditions."

"If one were to construct a model of the cameralist vision of the state, it would look like a model of a business firm," writes Wagner (2012, pp. 9-10). “The state's lands were potential sources of revenue. Forests could be harvested, game could be caught, and mines could be built and worked. The prince would also sponsor an assortment of commercial enterprises, including such things as the operation of a glassworks or a brewery." Treating the prince and his patrimony as a firm is defensible for several reasons. Internally, firms have a coherent chain of command for policing principal-agent problems - or if they do not, the market weeds them out, which makes it appropriate for social scientists to theorize about them thus (Alchian 1950; Becker [1971] 2017). The firm's goal is to make realized profits as large as possible. It has resources at its disposal and production technologies for turning those resources into marketable outputs. The prince faces similar conditions: his goal is to perpetuate his rule by deploying the resources at his disposal to greatest use. This includes making judgment calls, such as deciding to whom the 
prince should turn for advice and whom the prince should select for delegated managerial tasks. As Wagner (2012, p. 6), writes,

The prince was the ruler of his lands. He did not have to worry about surviving periodic elections, and he could hope to pass his principality along to his eldest son. His ability to do this, however, varied directly with the extent of economic progress within his land. A prince whose land was supporting a growing population of energetic and enterprising subjects would both be wealthier and face better survival prospects than a prince of a land where the population was stagnant or declining, and whose subjects were dull and lethargic. Furthermore, population was mobile in fact, even if it was mostly tied to the land at law through feudal restrictions. Distances between lands were typically short. A peasant who traveled to a new land was not likely to be returned. The rulers of the cameralist lands faced a competitive labor market. Indeed, the cameralist lands represented a kind of competitive industry among localized governments, much as Tiebout (1956) tried to characterize some 300 years later.

Thus, the first insight from cameralism is that, given the appropriate institutional context, the state can be conceived as a firm in competition with other firms. The prince plays the role of chief executive and largest shareholder: he makes managerial decisions and is a significant bearer of the resultant costs and benefits because of the effects on the prince's personal wealth, although obviously costs and benefits fall on his subject as well. In this context, control rights and residual claim rights are linked. Also, the above implies the state will be the chief locus of political entrepreneurship, as will be argued in subsequent sections.

\section{B. Public Finance as Private Enterprise}

If, to the cameralists, the state is a firm and the prince its chief executive, then how does the firm operate? What determines the firm's costs and revenues? Does the princely firm's specialization in producing governance, rather than more familiar goods and services, fundamentally change the state-firm's problem scenario? Due to intense political competition in post-Westphalia Germany, princes could not easily impose taxes. Excise taxes were a relatively recent innovation, and more well-known taxes, such as land and income 
taxes, "were thought to be poor means of raising revenue, because their relatively narrow bases required relatively high rates of tax to raise significant revenues, and those high rates were self-defeating through the incentives they created for various types of tax avoidance" (Backhaus and Wagner 1987, pp. 8-9).

The cameralist writers advised princes not to rely on taxation due to its disincentive effects on industry and what we would now call human capital accumulation. Instead, cameralists devised means for princes to use their own property to generate revenue. Thus, a significant body of the cameralist corpus contains principles of prudent management for forests, mines, steel mills, glass works, and even breweries. The content of this advice is not useful for current political entrepreneurship studies, but the manner in which cameralist writers dealt with the problem of governance revenues is. As Wagner (2012, pp. 11-12) writes,

The cameralists' general predisposition against taxation as an instrument of public finance reflects the orientation that the state acts as a participant within the economic order. Individuals had their property and the state had its property. The state should be able to use its property to generate the revenues required to finance its activities. Or at least those enterprise revenues should support the major portion of state activity. Some of the cameralists argued that taxes should be earmarked for the support of the military, while all activities concerned with internal development should be financed from the prince's net commercial revenues. In any case, the state contains many business enterprises within its boundaries ... with the state itself being one of those enterprises. The state's enterprises are to be the primary source of revenue for the state. It was understood that the state would have significant expenses associated with its activities. These expenses, however, were not to become drains upon the private means of subjects. They were to be met from the lands and enterprises that constituted the state's property.

Thus the second insight from cameralism is that the state-firm, with the prince at its head, was a part of commercial and civil society, rather than something above and distinct from it. Regime perpetuation was identified with wealth maximization, which entailed not only the efficient management of princely holdings but also respect for the persons and properties of subjects. "Run the state like 
a business" was not a cliché, but a valid means of understanding the problems associated with good governance: a rising tide lifts all boats, including the prince's (Backhaus and Wagner 1987, p. 8). The statefirm's revenues and costs are not thought of as abstract instruments of public policy, but as practical means for stewarding the wealth of the realm (Tribe 1984). The state may be the principal enterprise of the realm, but it is still an enterprise.

\section{Enlightened Absolutism as Mission Statement}

If we can think of the cameralist state as a firm, the prince as its chief executive and largest residual claimant, and the firm in the "business" of providing a bundle of governance goods as one politicalcommercial entity among many, what anchors the durability of princely reign? Every regime has a political formula (Mosca 1939) that legitimates rule. In the context of the cameralist state, this formula resembles a mission statement, a guiding philosophy for the governing apparatus and the appointees who staff it. This is where the political theory of enlightened absolutism becomes relevant.

Enlightened absolutism does not refer to a single, narrowlydefined political philosophy; instead it is a combination of justifications for princely rule that make recourse to various Enlightenment arguments concerning power, authority, and human nature (Krieger 1975). Nor is it a subset of cameralism. Instead, it is a complementary doctrine that, when coupled with the cameralist corpus, provides public coherence to private governance decisions by the prince and his managers. To simplify greatly: the "absolutist" component refers to the prince's role as the state's chief officer and to the insistence that his authority was not subject to curtailment; the "enlightened" component refers to the rationalist affinity for centralized and streamlined bureaucracies, the purpose of which was to better enable rulers to advance the public welfare, conceived chiefly in secular terms such as material well-being (Brunn 1929; Krieger 1970, 1975; Gagliardo 1967: Ingrao 1986). Enlightened absolutism was particularly useful to princes engaged in state building: "This legitimating principle was useful in providing German princes the authority they needed to begin centralizing rule within their polity, disrupting feudal-corporatist social arrangements that remained from the Middle Ages, such as self-governing prerogatives of the trade guilds and the landed aristocracy . . . the princes both asserted their growing prerogative as the sovereign head of a corporate organization distinct from him and his feudal patrimony 
(the nascent nation-state), and their historical role as landowning aristocrats guaranteeing their autonomy, especially from the Holy Roman Emperor" (Salter 2016, p. 10).

Thus, enlightened absolutism served as a mission statement for Germanic polities as they developed more centralized and internally coherent governance mechanisms. While the extent to which enlightened absolutist ideas influenced particular princes, and whether particular princes were "true believers" rather than opportunistic adherents to a doctrine that increased their power, varied greatly and is historically contentious (Ingrao 1986), enlightened absolutism still offered both goals and guideposts for Germanic princes in the early era of state building.

\section{Resumé}

Cameralism and enlightened absolutism are not themselves theories of political entrepreneurship. Instead, they establish the institutional antecedents within which political entrepreneurs operate, and from which the incentives and information confronting political entrepreneurs derive. The cameralist perspective on governance, and the enlightened absolutist perspective on the role of the prince, together provide the necessary context for reinterpreting Frederick the Great's philosophy of governance as a living theory of political entrepreneurship.

\section{Political Entrepreneurship in Frederick the Great's Anti- Machiavel}

The construction of modern states surely must be regarded as an important instance of political entrepreneurship, especially when considering Frederick's efforts with Prussia. Frederick was influenced by enlightened absolutism through his study of the French philosophes and his relationship with Voltaire. He was also influenced by cameralism and offered patronage to several highly regarded cameralist scholars (Small 1909, pp. 264-68). This background helps us understand how Frederick saw his project.

Anti-Machiavel is a chapter-by-chapter refutation of Machiavelli's The Prince. In its original form, Anti-Machiavel is a republication of The Prince, with Frederick's own analysis interspersed. Much of Machiavelli's advice to rulers, and hence Frederick's replies, is specific to the times of these authors. Thus it is no longer relevant to scholars of political entrepreneurship, or to political entrepreneurs themselves. What is of use is Frederick's orientation to his subject and how he 
views governing. It is from this broader perspective that we can derive useful knowledge for political entrepreneurship studies.

What follows is a selective analysis of Frederick's insights on ruling. I contend not that Frederick's personal political entrepreneurship was good (or bad), but that his philosophy represents a valuable, and hitherto neglected, way of thinking about the theory and practice of political entrepreneurship. All citations to and quotations from Anti-Machiavel come from the original English translation, published in London in 1791, and available online through Google Books. Page numbers are listed in parentheses, and quotes are recast to conform to modern spelling and grammar conventions.

Frederick and Machiavelli agree in a purely formal sense on the objectives of princely rule: perpetuation of the regime. However, for Frederick, this is only a proximate end. Here, the influences of cameralism and enlightened absolutism on Frederick are obvious. Frederick (p. 3) explicitly argues that the purpose of the prince is to serve the state, not that the purpose of the state to serve the prince: "A sovereign . . . was originally designed for the good of the people; this is therefore what a prince ought to prefer to every other consideration; and justice alone ought to be the guide of his actions. What becomes then of all those notions of self-interest, grandeur, ambition, and despotism [recommended by Machiavelli]; when it appears that the sovereign, far from being the absolute master of his people, is nothing more than their chief servant?" Furthermore, the chief activity of princes - warfare-rarely serves this end. Warfare is a legitimate, and even occasionally necessary, activity for an enlightened prince. But conquest is, at best, a risky and uncertain way to promote public welfare: "Since therefore it is not the extent of territory, but the number and wealth of inhabitants, that constitutes the strength and greatness of a state, a prince ought, for his own interest, to people his conquests, and render them flourishing, instead of destroying them and laying them to waste" (p. 47).

Frederick also agrees with Machiavelli that the character of princes matters. A Nero and a Marcus Aurelius are not substitutes; the qualities of a prince will necessarily be reflected in the state and impinge on the principality. This may seem so obvious that it does not merit mentioning. But in contemporary social science, explanations of large-scale social outcomes (such as governance quality and economic growth) that rely on personality and individual initiative have fallen out of favor. This is understandable and 
desirable; earlier writers and thinkers ascribed too much to will, intellect, and appetite, and not enough to impersonal mechanisms such as institutions. In modern liberal democracies, where governance is usually based on impersonal procedures instead of personal judgment, and is consensual (for those with a seat at the table, at least) rather than hierarchical, it is difficult for personalities to find expression in polity-wide governance.

But this institutional context was not Machiavelli's or Frederick's. Bonds of hierarchy and command were much more prevalent, and thus the attention paid to princes' characters makes sense. Where Frederick differs from Machiavelli is in his views on good leadership qualities. Frederick makes clear in the preface that the reason it so important to provide an alternative paradigm of statecraft to Machiavelli's is because the character of princes matters a great deal: "But if it is criminal to debauch the sentiments of a private person, who has but a small influence upon the affairs of the world; it is infinitely more to corrupt the morals of princes, whose business it is to govern nations, to administer justice, and to set examples of justice to their subjects ... Inundations which ravage countries, thunder and lightning that reduce cities to ashes, the pestilence which lays whole provinces to waste, are less fatal to the world than the vicious morals and unbridled passions of princes" (pp. vi-vii). Frederick elaborates on this theme especially in chapters six through nine, largely devoted to refuting Machiavelli's examples of prudent princes. In particular, Frederick has little love for Cesare Borgia, who to Machiavelli is the prince par excellence, but to Frederick is the prince whose emulation must be avoided at all costs.

Frederick offers a fresh perspective on the prince as a public figure. He is not fond of the quasi-medieval arrangement where governance is that which emerges out of the private agreements of the landed aristocracy, whether their counterparties be other lords, serfs, ecclesiastical officials, or chartered towns. While Frederick firmly believes governance is the private prerogative of the prince, this prerogative must always be oriented toward public purpose. Reflecting cameralist influences, to Frederick the institution of the state is separable from the prince, and the prince's chosen officials, who run it. He has only scorn for Machiavelli's examples of Italian princes who treated governance as something purely private, disregarding the public consequences of their behavior, and dismissively refers to them as "a fort of mongrels: half sovereign, half subject [private individual]" (p. 111). That is, they wanted to have it both ways: 
sovereigns when it suited them, subjects otherwise. To Frederick, this is a repudiation of the first responsibility of rule, which are the only foundation for the rights of rule.

The importance Frederick places on the reciprocal relationship of rights to responsibilities, and hence the benefits and costs of rule, can also be seen in his thoughts about princes at war: "Indeed a great king ought always to take upon him the command of his troops, and to look upon the camp as the place of his residence. This is what his interest, his duty and glory require: As he is the chief magistrate in distributing justice to his people, in times of peace, so he ought to be their chief protector and defender in war. .. As it is the prince himself who gives orders for the battle, it seems to be his province to direct the execution of them, and by his presence and example to inspire his troops with valor and confidence" (pp. 133-35).

Yet Frederick recognizes the urge to take charge must be tempered by an appreciation for the division of labor within the state. A prince may not be the princedom's best general. "This objection may be easily removed: A prince will always find generals skillful enough to advise and it is sufficient for him, in this case, to be directed by their advice," Frederick writes. "Besides, no war can be carried on with great success if the general is under the direction of a ministry who are not present in the camp, and consequently not able to judge of sudden occurrences, and give orders accordingly" (pp. 134-136). Thus the prince can and should delegate high command if the situation calls for it, but should always be physically present in some theater of war, as proof of his willingness to accept the same risks as his soldiers.

The influence of cameralism can also be seen in Frederick's views on the prince's commercial role. Frederick thinks about economic policy very differently than it is thought of today. Economic policy is not abstract, in the manner of a social planner trying to correct particular market deficiencies. For a prince, economic policy is conducted within the commercial sphere, by the prince deploying his personal capital. While the prince is responsible for the smooth operation of commerce, he is not the commercial system. This can be seen in Frederick's views on liberality and frugality, and how each virtue is differentially important in small vs. large principalities. It can also be seen in Frederick's departure from standard policy advice of the time, which encouraged rulers to stockpile precious metals in case they needed to mobilize an army on short notice: "Every private man, as well as every king, who knows only how to heap up and hide 
money, impoverishes others without enriching himself . . Let every sovereign therefore endeavor to enrich himself by encouraging commerce and other manufactures, that he may be able to spend much when occasion requires" (pp. 175-77).

Frederick devotes significant attention to how princes contribute to, or detract from, the material prosperity of their realms. Unusually for an eighteenth-century prince, especially one so skilled in war, Frederick has many positive things to say about princes who attain greatness "by good government, when an industrious prince encourages all the arts and sciences" rather than by warfare. While the latter may be the more traditional path to glory, to Frederick the former "is much more innocent and just ... and not less useful" (p. 263). Much of chapter 21 is spent describing strategies princes can adopt to encourage commerce and manufacturing, as well as arts and sciences, and the reasons it is in a prince's interest to do so.

The final theme of Frederick's which is relevant for modern entrepreneurship studies is the role of personal judgment in exercising sovereign command. Frederick is clear, and even eloquent, in his insistence that the burden of sovereignty ultimately fall on the prince:

The most precious deposit that is put in the hands of a prince is the lives of his subjects: As his office gives him a power of condemning to death, or pardoning criminals, so it makes him the supreme arbiter of justice. Good princes look upon this power, which is so much boasted of, as the weightiest part of their charge ; they know they are men themselves, as well as those whom they judge; they know that injustices and injuries may be compensated in this world, but that the execution of a sentence of death too hastily passed, is an evil that can never be repaired; they are only inclined to severity, when they find severity necessary to prevent greater evils, which otherwise could not be averted; they are always merciful, except in desperate cases, where mercy to particulars would be cruelty to the whole; and act like a man, who having a leg or an arm gangrened and incurable, is willing to bear the painful operation of having it cut off, in order to save the rest of his body (pp. 179-81).

Frederick is not against planning. In fact, his affinity for French Enlightenment thought predisposes him to favor rationalistic approaches to governance: "Every reasonable man, and especially 
those whom Heaven hath appointed to govern others, ought to lay down some plan of their conduct, and to make it as well connected and as conclusive as a geometrical demonstration: By closely adhering to such a system, they will be sure to act consistently, without ever departing from their main design" (p. 312). But it is still the prince's responsibility to come up with the plan and execute it, and the planning process itself cannot be the result of impersonal reason. There is no such thing as government by algorithm, and Frederick is dismissive of attempts to remove human judgment from the act of rule: "Fondness for system is not a folly peculiar to philosophers, but grown common to them and politicians" (p. 200). To Frederick, although particular acts of rule can and should be delegated, the prince must never repudiate ultimate decision-making authority. Active and engaged princes "are the life and soul of their dominions; the weight of their government rests upon themselves, like the world upon the shoulders of Atlas; they regulate affairs both foreign and domestic; and fill at once the posts of first magistrate of justice, of general of the armies, and of high treasurer . . . their ministers are properly no more than the tools and utensils of a skillful artificer" (pp. 274-75).

\section{Frederick the Great's Lessons for Political Entrepreneurship Studies}

In analyzing Frederick's perspective, we immediately confront an intriguing and hitherto underappreciated aspect of political institutions that affects how political entrepreneurship manifests in specific historical settings. Today, political actors are not residual claimants to the state's activities; in Frederick's time, they were. Appreciating this difference allows us to understand why Frederick's approach to political entrepreneurship matters: it is a way of thinking where political entrepreneurship and commercial entrepreneurship are directed toward the same ends-stewardship of the polity's resources-and can be judged according to the same feedback procedures for ascertaining value creation and value capture (Klein et al. 2013).

The institutional analogue of the political entrepreneur is the political-entrepreneurial state. As feudal political-economic conditions faded away and those of early modernity solidified, the states acquired institutional identities separate from the patrimony of the princes who headed them. The advice preferred by the cameralist writers, polity wealth maximization as a means to regime 
perpetuation, constitutes a fairly well-defined objective for princely rule, and hence a criterion for ascertaining ex ante forecasts of particular activities and assessing ex post the efficacy of such activities. This is an important feedback mechanism that can help rulers understand which policies contribute to good governance, and which do not.

Frederick's perspective on rule provides us a window into political entrepreneurship at a time when the state was particularly firm-like, allowing us to see political entrepreneurship in the wild. Political entrepreneurship in today's states can be obscured by complex de jure decision procedures, and further complicated because those procedures often differ from de facto decision procedures. This complexity makes political entrepreneurship difficult to find, isolate, and study. In the Germanic principalities, such as Frederick's Prussia, the locus of political entrepreneurship is much more concrete: the hierarchy of state activities undertaken by those to whom the prince delegated authority, culminating in the prince himself. Frederick's Anti-Machiavel thus provides us a window into the theory of political entrepreneurship, in a context where political entrepreneurship and market entrepreneurship were relatively analogous.

We now can be precise about what Frederick's Anti-Macbiavel offers for contemporary political entrepreneurship studies. The first relevant theme from Anti-Machiavel is already recognized in the literature, but it bears repeating briefly. Political entrepreneurship is not in essence different from market entrepreneurship. On the judgment-based view of entrepreneurship, whether acting in market or nonmarket settings, entrepreneurship means (a) decision-making under uncertain conditions that (b) entails the actor bearing costs and benefits associated with executing a plan by (c) allocating scarce resources to bring about a more preferred state of affairs. Both market and political entrepreneurs employ hierarchies in carrying out their plans: the former use firms, the latter use states. In an extension of Foss and Klein (2012), which develops the judgment-based view by linking it to the theory of the firm, the state is the institution within which political entrepreneurs exercise judgment.

The second theme is genuinely novel. Frederick directs our attention to a new type of entrepreneurship that is a subset of political entrepreneurship. This is sovereign entrepreneurship. The sovereign entrepreneur sits at the top of a governance hierarchy, which can be described as a pyramid of political property rights 
(Salter 2015a, b). A sovereign necessarily enforces his own political property rights, rather than delegating enforcement to another. Whether formal or informal, political property rights determine who may make political decisions, what the costs and benefits of these decisions are, and to whom the costs and benefits accrue. In the market context, Foss and Klein (2012, chap. 8) develop a theory of original vs. delegated entrepreneurial judgment. Firms are the nexus of entrepreneurial judgment because judgment cannot be traded on the market, and so cannot be contracted out by the firm. Specific judgment-making instances may be contracted or delegated; firms frequently hire consultants, and almost always have more than a single employee. But the decision to contract or delegate is itself a judgment call. Ultimately, the right of original judgment remains with the entrepreneurial firm at the apex of its hierarchy. The Hobbesian logic makes this framework readily applicable to political entrepreneurship. In a political context, Frederick is describing princes as sovereign entrepreneurs: political entrepreneurs who can delegate specific judgment rights, but not the ultimate right of original judgment.

Sovereign entrepreneurs, as the apex of the state hierarchy, are free from the constraints created by the hierarchy to advance the entrepreneur's plans, or to mitigate principal-agent problems that would hinder the plan. But sovereign entrepreneurs are still constrained: they still confront trade-offs, frequently because a sovereign entrepreneur's plans conflict with the plans of other sovereign entrepreneurs. Whether sovereigns compete or cooperate, or do both on different margins, is determined by original entrepreneurial judgment: the higher up the political property rights hierarchy, the less concrete costs and benefits become (e.g., Martin 2010), and the more important judgment becomes. The sovereign cannot delegate original judgment to another; if he does, he is no longer a sovereign, but an agent of some other sovereign. Frederick repeats this theme in his stated preference for princes who take an active role in managing their principality, rather than delegating all essential tasks to subordinates (pp. 274-76). This is why Frederick's insights on political entrepreneurship are relevant to the literature on private governance cited in the introduction: sovereign entrepreneurs are in a "state of nature" with respect to each other, because there is no super-sovereign to whom they can appeal to settle disputes.

The third insight is related to sovereign entrepreneurship, but is conceptually distinct. It has to do with the alignment of sovereign 
entrepreneurs' incentives with those over whom they exercise authority. Sovereign entrepreneurship entails high-stakes judgment calls. A prince who makes poor decisions may be deposed, and his principality occupied and plundered. But the costs of having his realm devastated greatly exceed the personal cost associated with being deposed. As the exerciser of the state-firm's original judgment, the prince's decisions will almost always result in relatively more costs and benefits accruing to others than accrue to the prince personally, even if the latter are large in an absolute sense.

Frederick's recognition of this asymmetry motivates his advice that princes put themselves in a position where they bear as large a share of the consequences of their decisions as possible (pp. 133-36). When armies are in the field, the prince must march with them. When trade and manufacturing slow down, the prince must support commerce with his personal capital. When entering into treaty agreements with other princes, the prince must not defect from these agreements in the pursuit of temporary personal benefits when defection entails long-term costs. Both for the sake of private virtue and public commitment, princes must be diligent in reducing consequence asymmetry, and should never govern in a manner that privatizes benefits but socializes costs.

The final insight concerns the sovereign entrepreneur's economic role. The Adam Smith quote at the beginning of this paper was widely considered a maxim of good governance during the era of classical and early neoclassical economics. But with the transformation of the art of political economy into the science of economics, beginning in the late nineteenth century and culminating after the Second World War, a very different approach to public policy economics prevailed. The economic role of the state had changed, not only in terms of policy content, but also in terms of the foundational concepts used to describe and derive this content (Boettke and Leeson 2015). Abstract notions of social welfare rose to prominence as normative criteria. State revenues and outlays were viewed instrumentally as tools of economic control. An engineering mindset replaced an ecological mindset among both scholars and policy analysts.

While much of the content in this paradigm has changed since its inception, the paradigm itself remains in place. Frederick's perspective recalls a time when Adam Smith's maxim was normative. The prince is sovereign, but even the sovereign has a capital stock he is looking to preserve, and a budget constraint that must be obeyed. 
In commercial matters, the prince may have the loudest voice, but he is speaking the same language as his subjects. As both a student and patron of the cameral sciences, and as the polity's "largest estateowner, largest banker, and supreme aristocratic magistrate" (Krieger 1975, p. 31), Frederick saw the prince's private holdings as objects of personal stewardship and as inputs for the state-firm. In matters of trade, the prince's role was to promote the wealth of his subjects, which as a consequence would promote his personal wealth. In Frederick's writings, we see content ascribed to the commercial goals of political entrepreneurship that, at least formally, resemble the concerns of the classical political economists more than three decades before their classic statement by Adam Smith.

Taken collectively, the insights derived from Anti-Machiavel suggest that political entrepreneurship can, given the appropriate institutional context, take its cues from commercial entrepreneurship. The political-entrepreneurial state can be a driver of economic value in the same manner as the entrepreneurial firm, with each reflecting acts of judgment-delegated or not-pertaining to the direction of scarce resources under uncertainty. As Bernier and Hafsi (2007, p. 488) note, this idea is not new. But it has received comparatively little attention in the literature. In a well-cited article on political entrepreneurship, Klein et al. (2010, p. 1) argue that "public and private entrepreneurship share essential features, but differ critically regarding the definition and measurement of objectives." As a general category, and especially with application to modern democracies, Klein et al. are certainly correct. But the devil is in the details. Drawing on Frederick, I have shown that in particular cases, such as historical episodes of state development where political entrepreneurs were residual claimants ("owners of the realm"), it is not just that "public and private entrepreneurship share essential features"; these two kinds of entrepreneurship can, "regarding the definition and measurement of objectives," be treated as homologues. This seemingly small change opens up new worlds for the application of political entrepreneurship paradigms. For example, rather than being limited to understanding opportunities, innovation, and change in current public organizations, political entrepreneurship frameworks can be used to study the rise of political and economic modernity itself. Such a drastic increase in the valid scope of political entrepreneurship paradigms would not have been apparent but for an appreciation for Frederick's thoughts on the subject. 


\section{Conclusion}

I have argued that Frederick II of Prussia, in his Anti-Machiavel, offers a perspective on governing that can advance modern political entrepreneurship studies. With appropriate appreciation for the intellectual context for his writings, Frederick's exhortations to princes show us that political entrepreneurship involves exercising judgment in the use of the state apparatus; that the necessity of original judgment implies the existence of sovereign entrepreneurs; that it is imperative for political entrepreneurs, and especially sovereign entrepreneurs, to have 'skin in the game'; and that political entrepreneurs can promote their polities' material prosperity by acting within markets, operating by the same logic as other commercial organizations.

Scholars of political entrepreneurship may question the relevance of Frederick's perspective to contemporary political conditions. As I noted earlier, currently existing states differ greatly from those that Frederick took for granted. Whereas Frederick spoke in terms of command and personal judgment, today we speak in terms of consent and standardized procedures. In Frederick's time, the public administrative bodies of states were relatively simple. Today's are highly complex, and de facto authority frequently differs from de jure authority. However, this modern structure may make Frederick's insights more useful, not less.

An analogy with economic models can make this point clearer. The model of perfect competition is an important part of the economist's toolkit. This model makes highly unrealistic assumptions (price taking by firms, perfect information, zero transaction costs, etc.) to isolate how variables at the firm level and the market level affect each other. But this is not the most fruitful use of the model. Such models in economics are not roadmaps, but foils (Mises 1949; Albrecht and Kogelmann 2017). The model of perfect competition helps economists understand how markets work by juxtaposing the model with reality; the differences between the two draw economists' attention to interesting problems. Counterintuitively, a powerful method for understanding the dynamic aspects of market competition begins with a static model of market competition. Likewise, theories of political entrepreneurship informed by Frederick's writings can be juxtaposed with real state institutions and how political entrepreneurship operates within them. There will be many differences, some irreconcilable. But this is precisely how we discover the problems to which scholarly efforts are best directed. 
Entrepreneurship means acting under uncertainty to advance a plan; this is a universal facet of human action, identical across institutional contexts. Political entrepreneurship adds the specific institutional context of the state. Students of political entrepreneurship can focus on institutionally contingent theory (Leeson and Boettke 2006, p. 249), which should yield predictions of how sovereign entrepreneurs, or political entrepreneurs more generally, behave in different settings. Current states use much of the social-political technology that Frederick and his contemporaries pioneered. The difference is that in today's states, this apparatus comprises an order, not an organization, because statewide mechanisms for reconciling plans and policing principal-agent problems are weak.

Political entrepreneurship unquestionably occurs in modern states. But instead of a sovereign who confronts a hard budget constraint and is a residual claimant to his activities, we have a network of (de facto) sovereigns, all of whom confront soft budget constraints (Kornai 1986) and are not residual claimants. If the cameralist state resembles a firm, modern states more resemble employee-owned cooperatives. The former have goals set by executive fiat; the latter have a plurality of objectives that arise from continuous discussion and bargaining. Thus sovereign entrepreneurship should look quite different in today's states than in those of early modernity due to significant differences in institutional context.

Having discovered sovereign entrepreneurship and arrived at an appreciation for its dependence on institutional contexts, we can now consider how the concept can be put to work. The first avenue is the massive literature, dating back to Baumol's (1990) famous paper, on the relationship between entrepreneurship and economic prosperity. Healthy economies provide entrepreneurs the incentives and information they need to be productive, rather than unproductive or destructive. Unhealthy economies do the opposite. This literature has focused mostly on the market entrepreneur. The role of the political entrepreneur has received considerably less attention.

But if markets require specific institutional antecedents to create wealth, and these antecedents largely come from states, we need to understand the incentives and information confronting the political entrepreneurs who built these states as well. Frederick's political entrepreneur-the sovereign entrepreneur-is the link that can bring together the various literatures in economics, political science, 
entrepreneurship and management studies, and public administration that explore various facets of social science's perennial question: the causes of the wealth and poverty of nations.

More immediately, sovereign entrepreneurship can be used to study administration, governance, and economic growth in states that most closely resemble those of Frederick's time. These states are likely to be small, either geographically or in population, and to have a tight administrative apparatus with a coherent decision structure. States such as the United Arab Emirates, Liechtenstein, and Singapore fit this description. They are also notable for being "growth miracles": rapid economic growth within the last few decades has propelled their per capita income to levels comparable to or above those of Western economies. But many other small states have not achieved similar material prosperity. The difference is probably institutions. We know that the rules of the game are an important determinant of the wealth of nations. Exploring the incentives and information sovereign entrepreneurs confront in these kinds of polities can shed light on why rules differ across polities, as well as the development of commercial-friendly rules within a given polity.

Finally, I will say a few words about personal vs. impersonal factors in political entrepreneurship studies. Constraints on political entrepreneurs usually bind less tightly than on market entrepreneurs. This is even truer for sovereign entrepreneurs, who exercise original judgment. Theories that incorporate judgment must have room for personal characteristics to influence social outcomes. The danger here is focusing too much on these characteristics. Doing so runs the risk of reducing political entrepreneurship studies to Carlylean "Great Man" theories of history, and reducing those who do such studies to biographers.

While taking political entrepreneurship seriously means paying attention to personal factors, as in Newman (2018), the paradigm I suggest in this paper safeguards against reducing everything to will or preferences. Frederick's political entrepreneur, including the sovereign entrepreneur, requires a specific institutional environment. Just as Foss and Klein (2012) develop the theory of the entrepreneurial firm, drawing on Frederick I have shown the importance of the political-entrepreneurial state. Actor and institution are necessarily wedded; jettisoning the latter also eliminates any justification for incorporating the former into the analysis. 


\section{References}

Acemoglu, Daron, Davide Ticchi, and Andrea Vindigni. 2011. "Emergence and Persistence of Inefficient States." Journal of the European Economic Association, 9(2): 177-208.

Acemoglu, Daron, Camilo Garcia-Jimeno, and James A. Robinson. 2015. "State Capacity and Economic Development: A Network Approach." American Economic Review, 105(8): 2364-2409.

Acemoglu, Daron, Jacob Moscona, and James A. Robinson. 2016. "State Capacity and American Technology: Evidence from the Nineteenth Century." American Economic Review, 106(5): 61-67.

Agarwal, Rajshree, Jay B. Barney, Nicolai J. Foss, and Peter G. Klein. 2009. "Heterogeneous Resources and the Financial Crisis: Implications for Strategic Management Theory." Strategic Organization, 7(4): 467-84.

Albrecht, Brian C., and Brian Kogelmann. 2017. "Models as Foils.” Working paper.

Alchian, Armen A. 1950. "Uncertainty, Evolution, and Economic Theory." Journal of Political Economy, 58(3): 211-21.

Anderson, Terry and Peter J. Hill. 2004. The Not So Wild, Wild West: Property Rights on the Frontier. Stanford, CA: Stanford University Press.

Backhaus, Jurgen, and Richard E. Wagner. 1987. "The Cameralists: A Public Choice Perspective." Public Choice, 53(1): 3-20.

Backhaus, Jurgen, and Richard E. Wagner. 2005. "From Continental Public Finance to Public Choice: Mapping Continuity." History of Political Economy, 37 (December supplement): 314-32.

Barzel, Yoram. 1997. Economic Analysis of Property Rights. Cambridge: Cambridge University Press.

Baumol, William J. 1990. "Entrepreneurship: Productive, Unproductive, and Destructive." Journal of Political Economy, 98(5): 893-921.

Becker, Gary. [1971] 2017. Economic Theory. New York: Routledge.

Beckett, Julia. 2000. "The 'Government Should Run Like a Business' Mantra." American Review of Public Administration, 30(2): 185-204.

Bernier, Luc, and Taiib Hafsi. 2007. "The Changing Nature of Public Entrepreneurship." Public Administration Review, 67(3): 488-503.

Besley, Timothy, and Torsten Persson. 2009. "The Origins of State Capacity: Property Rights, Taxation, and Politics.” American Economic Review, 99(4): 121844.

Besley, Timothy, and Torsten Persson. 2010. "State Capacity, Conflict, and Development." Econometrica, 78(1): 1-34.

Besley, Timothy, and Torsten Persson. 2011. Pillars of Prosperity: The Political Economics of Development Clusters. New Haven, CT: Princeton University Press.

Bjerregaard, Toke, and Jakob Lauring. 2012. "Entrepreneurship as Institutional Change: Strategies of Bridging Institutional Contradictions." European Management Review, 9(1): 31-43.

Block, Joern H., Christian O. Fisch, and Mirjam van Praag. 2017. "The Schumpeterian Entrepreneur: A Review of the Empirical Evidence on the Antecedents, Behavior, and Consequences of Innovative Entrepreneurship." Industry and Innovation, 24(1): 61-95.

Boettke, Peter J. 2011. "Anarchism and Austrian Economics." New Perspectives on Political Economy, 7(1): 125-40. 
Boettke, Peter J., and Peter T. Leeson, eds. 2015. The Economic Role of the State. Cheltenham, UK: Edward Elgar.

Brunn, Geoffrey. 1929. The Enlightened Despots. New York: Henry Holt.

Bysted, Rune, and Kristina Risom Jespersen. 2014. "Exploring Managerial Mechanisms that Influence Innovative Work Behavior: Comparing Private and Public Employees." Public Management Review, 16(2): 217-41.

Caplan, Bryan, and Edward P. Stringham. 2008. "Privatizing the Adjudication of Disputes." Theoretical Inquiries in Law, 9(2): 503-28.

Coase, Ronald. 1937. "The Nature of the Firm." Economica, 4(16): 386-405.

Ellickson, Robert C. 1991. Order Without Law. Cambridge, MA: Harvard University Press.

Foss, Nicolai, and Peter G. Klein. 2012. Organizing Entrepreneurial Judgment: A New Approach to the Firm. Cambridge: Cambridge University Press.

Frederick II, King of Prussia. [1740] 1791. Anti-Machiavel: Or, an Examination of Machiavel's Prince, with Notes Historical and Political. London: T. Woodward.

Friedman, David. 2014. The Machinery of Freedom: Guide to a Radical Capitalism, 3rd ed. Open Court Publishing Company.

Gagliardo, John G. 1967. Enlightened Despotism. New York: Thomas Y. Crowell.

Gennaioli, Nicola, and Hans-Joachim Voth. 2015. "State Capacity and Military Conflict." Review of Economic Studies, 82(4): 1409-48.

Hart, Oliver D. 1995. Firms, Contracts, and Financial Structure. Oxford: Clarendon.

Hayek, Friedrich A. 1973. Law Legislation, and Liberty, Vol. 1: Rules and Order. Chicago: University of Chicago Press.

Ingrao, C. 1986. "The Problem of 'Enlightened Absolutism' and the German States." The Journal of Modern History, 58 (December supplement): S161-S180.

Johnson, Noel D., and Mark Koyama. 2017. "States and Economic Growth: Capacity and Constraints." Explorations in Economic History, 64(1): 1-20.

Kirzner, Israel. 1973. Competition and Entrepreneurship. Chicago: University of Chicago Press.

Kirzner, Israel. 1997. "Entrepreneurial Discovery and the Competitive Market Process: An Austrian Approach." Journal of Economic Literature, 35(1): 60-85.

Kivleniece, Ilze, and Bertrand V. Quelin. 2012. "Creating and Capturing Value in Public-Private Ties: A Private Actor's Perspective." Academy of Management Review, 37(2): 272-99.

Klein, Peter G., Joseph T. Mahoney, Anita M. McGahan, and Christos N. Pitelis. 2010. "Towards a Theory of Public Entrepreneurship." European Management Review, 7(1): 1-15.

Klein, Peter G., Joseph T. Mahoney, Anita M. McGahan, and Christos N. Pitelis. 2013. "Capabilities and Strategic Entrepreneurship in Public Organizations." Strategic Entrepreneurship Journal, 7(1): 70-91.

Kling, Arnold. 2016. Specialization and Trade. Washington, DC: Cato Institute.

Knight, Frank H. 1921. Risk, Uncertainty, and Profit. New York: August M. Kelley.

Koppl, Roger. 2018. Expert Failure. Cambridge: Cambridge University Press.

Kornai, Janos. 1986. “The Soft Budget Constraint.” Kyklos, 39(1): 3-30.

Krieger, Leonard. 1970. Kings and Philosophers, 1689-1789. New York: W. W. Norton.

Krieger, Leonard. 1975. An Essay on the Theory of Enlightened Despotism. Chicago: University of Chicago Press. 
Leeson, Peter T. 2011. "Government, Clubs, and Constitutions." Journal of Economic Behavior and Organization, 80(2): 301-08.

Leeson, Peter T. 2014. Anarchy Unbound: Why Self-Governance Works Better Than You Think. Cambridge: Cambridge University Press.

Leeson, Peter T., and Peter J. Boettke. 2006. "Was Mises Right?" Review of Social Economy, 64(2): 247-65.

Leyden, Dennis, and Albert Link. 2015. Public Sector Entrepreneurship: US Technology and Innovation Policy. Oxford: Oxford University Press.

Machiavelli, Niccolo. 1532. The Prince. Many editions and translations.

Martin, Adam. 2010. "Emergent Politics and the Power of Ideas." Studies in Emergent Order 3: 212-45.

Martin, Adam and Diana Thomas. 2013. "Two-Tiered Political Entrepreneurship and the Congressional Committee System.” Public Choice, 154(1-2): 21-37.

McCaffrey, Matthew and Joseph Salerno. 2014. "A Theory of Political Entrepreneurship." Modern Economy, 2(4): 552-60.

McGinnis, Michael D., and Elinor Ostrom. 2012. "Reflections on Vincent Ostrom, Public Administration, and Polycentricity." Public Administration Review, 72(1):15-25.

Mises, Ludwig von. 1949. Human Action: A Treatise on Economics. New Haven, CT: Yale University Press.

Mosca, Gaetano. 1939. The Ruling Class. New York: McGraw-Hill.

Newman, Patrick. 2018. "Revenge: John Sherman, Russell Alger, and the Origins of the Sherman Act." Public Choice, 174(3-4): 257-75.

Ostrom, Elinor. 2005. "Unlocking Public Entrepreneurship and Public Economies.” Working Paper DP2005/01, World Institute for Development Economic Research (UNU-WIDER).

Powell, Benjamin, and Edward P. Stringham. 2009. "Public Choice and the Economic Analysis of Anarchy: A Survey." Public Choice, 140(3-4): 503-38.

Salter, Alexander W. 2015a. "Rights to the Realm: Reconsidering Western Political Development." American Political Science Review, 109(4): 725-34.

Salter, Alexander W. 2015b. "Sovereignty as Exchange of Political Property Rights." Public Choice, 165(1): 79-96.

Salter, Alexander W. 2016. "Post-Cameralist Governance: Towards a Robust Political Economy of Bureaucracy." Economic Affairs, 36(3): 294-308.

Schumpeter, Joseph. 1911. The Theory of Economic Development. Cambridge, MA: Harvard University Press.

Schumpeter, Joseph. 1939. Business Cycles: A Theoretical, Historical, and Statistical Analysis of the Capitalist Process. New York: McGraw-Hill.

Shane, Scott. 2003. A General Theory of Entrepreneurship. Cheltenham, UK: Edward Elgar.

Shane, Scott, and S. Venkataraman. 2000. "The Promise of Entrepreneurship as a Field of Research." Academy of Management Review 25: 217-26.

Skarbek, Emily. 2016. "Aid, Ethics, and the Samaritan's Dilemma: Strategic Courage in Constitutional Entrepreneurship." Journal of Institutional Economics, 12(2): 371-93.

Small, Albion. 1909. The Cameralists: The Pioneers of German Social Polity. Chicago: University of Chicago Press.

Stringham, Edward P. 2015. Private Governance: Creating Order in Economic and Social Life. New York: Oxford University Press. 
Stringham, Edward P., and Todd J. Zywicki, 2011. "Hayekian Anarchism." Journal of Economic Behavior \& Organization, 78(3): 290-301.

Tiebout, Charles M. 1956. "A Pure Theory of Local Expenditures." Journal of Political Economy, 64(5): 416-24.

Tribe, Keith. 1984. "Cameralism and the Science of Government." Journal of Modern History, 56: 263-84.

Van Stel, André, Martin Carree, and Roy Thurik. 2005. "The Effect of Entrepreneurial Activity on National Economic Growth." Small Business Economics, 24(3): 311-21.

Wagner, Richard E. 2012. "The Cameralists: Fertile Sources for a New Science of Public Finance." In Handbook for the History of Economic Thought, ed. J. Backhaus. Dordrect, Netherlands: Springer.

Wagner, Richard E. 2016. Politics as a Peculiar Business: Insights from a Theory of Entangled Political Economy. Cheltenham, UK: Edward Elgar.

Weber, Max. [1918] 1946. "Politics as a Vocation." In From Max Weber, ed. and trans. H. H. Gerth. New York: Free Press.

Williamson, Oliver E. 1996. The Mechanisms of Governance. Oxford: Oxford University Press. 